\title{
Geoelectrical characterization of rock formations underlying Idonyi River, Amaeke-Abam, Southeastern Nigeria
}

\section{Nnokwe Ndidiamaka Nchedo, Ibe Kalu Kalu, Ibeneme Sabinus Ikechukwu*, Selemo Alexander Olusegun, Nwagbara Johnbosco Okechukwu}

Geosciences Department, Federal University of Technology Owerri Nigeria

Email address:

peseesabim@gmail.com (I. S. Ikechukwu)

\section{To cite this article:}

Nnokwe Ndidiamaka Nchedo, Ibe Kalu Kalu, Ibeneme Sabinus Ikechukwu, Selemo Alexander Olusegun, Nwagbara Johnbosco Okechukwu. Geoelectrical Characterization of Rock Formations Underlying Idonyi River, Amaeke-Abam, Southeastern Nigeria. American Journal of Physics and Applications. Vol. 2, No. 1, 2014, pp. 35-45. doi: 10.11648/j.ajpa.20140201.15

\begin{abstract}
The geoelectrical characterization of soils underlying the Idonyi River Dam site Amaeke-Abam, Southeastern Nigeria has been carried out with a view to determining the presence or otherwise of deleterious matter along the dam axis down to a depth of $37 \mathrm{~m}$ below the surface; evaluate the geo-structural setting of the concealed bedrock, the fracture pattern and possible dam seepage along the dam axis and its banks as well as giving suggestions on any other measures/studies that may be needed for a proper engineering design. The study area is around the river located between latitudes $5^{\circ} 34^{\prime} \mathrm{N}-$ $5^{\circ} 37^{\circ} \mathrm{N}$ and longitudes $7^{\circ} 39^{\prime} \mathrm{E}-7^{\circ} 42^{\prime} \mathrm{E}$. Heights above sea level in the area range from 68 to 91 meters. The survey was carried out with Abem Terrameter SAS 1000C. The sounding stations were laid out in three (3) profiles; eight (8) VES on each profile. A total of twenty-four (24) VES data were conducted. The Schlumberger electrode configuration was adopted to a total spread length of 110 meters $(\mathrm{AB} / 2$ of 55 meters). Results showed that resistivity values of between 182 and $2637 \Omega \mathrm{m}$ at the eastern part of the River and another range of 6.2 to $848 \Omega \mathrm{m}$ in the western end suggest overriding sandy substratum to east and overriding shaly characteristics to the west. These results show clearly that the area around Idonyi is porous with relatively higher sandy fractions. The derived parameters on both sides of the river agreed with the standard parameters required for a dam construction. The failure of a previous dam near the river is thus attributable to much seepage due to overriding sandy substratum. To avoid the seepage, the base of the dam should be blanketed with an impervious material such as shale. The area, being the most fertile area (phosphatic Ameki units) with CRIN, NRRI, FRIN, RCRIN having research institutes near the river, a dam is necessary here and this study has shown that it is possible to have a dam with solid foundation. However, we suggest a baseline data survey of water quality before any construction so as to monitor any contamination trend due to impoundment.
\end{abstract}

Keywords: Amaeke-Abam, Geoelectric Section, Iso-resistivity, Lithology, Schlumberger, Seepage

\section{Introduction}

The world over, there is no form of agriculture that can be practised without having a fertile soil, adequate water and good weather conditions in favourable measures. Soil is a product of chemical, biological and mineralogical activities in the subsurface. Rocks disintegrate to give soils (the richer the rock products are in different trace elements, the richer the soil). These go with different geological formations. While some are rich due to the underlying rocks, others are poor in plant nutrients. When all things pertaining to soil are correct then water is the next problem when not in place. Some geological formations have huge sub-surface water while others do not on account of rock type and structure as well as stratigraphic relationships. It is possible to impound a body of water for agriculture, domestic and industrial activities. Since water is a universal solvent, it dissolves minerals in the soil so that plants will absorb the necessary nutrients. Amaeke Abam/Bende area is fertile. This is the reason for the estabilishment of four (4) Federal Research Institutes in the area viz (1) Cocoa Research Institute of Nigeria (CRIN), (2) National Rice Research Institute (NRRI), (3) Root Crop Research Institute of Nigeria (RCRIN) along Uzuakoli Road and (4) Forestry Research Institute (FRIN). During the dry months 
of Novermber - March there is insufficient water supply for agricultural practices. Therefore there is need for a dam to be in place. Such a dam must have adequate foundation study to enable structural design by experts. For ages, the engineering of dams has evolved from crude works to increasingly complex systems. Ancient dam construction was a tentative art drawn from simple experimentation. The early dam builders made practical use of alluvium that was readily available along streams. They created precarious embankments, easily erased by floods. Consequently, earthfills inspired little confidence for thousands of years. Dams made of rock materials were favoured in many parts of the world. In the Wadi el-Garawi dam near Helwan in Egypt are remnants of Sadd el - Kafara dam which date from as early as $2600 \mathrm{BC}$ to $2900 \mathrm{BC}$. It was a $46 \mathrm{ft}-\mathrm{high}$ (14 meters) rockfill with cut-stone masonry faces and a core of rubble and gravel. The central section is assumed to have been destroyed by flood soon after or in the final stage of construction. The core materials were not well protected from erosion. Insufficient provision for spill was responsible. This has been the case for the failures of many dams throughout history [1]. As the centuries unfolded, craftmanship improved. The Romans constructed many dams of very durable mortarted masonry. Some of them are still in service. Their large spill-ways attesting to the Roman understanding of engineering fundamentals. Some historians believe that the Romans were the originators of the arch dams. An impresssive structure of this type was built on a tributary of the Khabur River near Daras on the Turkish -Syrian border [1]. A notable dam of the Mongol Period in Persia was built in a narrow gorge on the Kebar River about 15 miles $(24 \mathrm{~km})$ south of the town of Qum. In Mexico, the rubble - masonry buttressed type was adopted at many sites [1]. Effective dam egineering requires respect for the destructive potential of uncontrolled water. To ensure that its force is subdued, it must be excluded or confined to safe passages. A dam will alter the natural equilibrum at the site. As water is impounded, a new regime of seepage will develop in the barriers that form the reservoir. The characteristics of materials in the dam and in its foundation will change, causing a transition in the capabilities of the structure [1]. Soil and rock are interrelated though soil can be defined as the loose fragments of rocks [2]. Subsoil or sub-surface is the general name for all the zones beneath the surface of the earth. It goes down to the earth crust and down to the centre of the earth. Faults investigations in dam designs continue to be an evolving technology subject to new scientific developments and considerable judgement. Every dam site does not require the same level of fault investigation: a well planned and executed geologic investigation for most dam site will provide the data required for the seismic assessment and identify those sites wherein more extensive seismotectonic investigations are required [3]. Geophysical methods are now worldwide standard components for preliminary investigation at potential dam sites, and at the proposed locations of many types of facilities such as gigantic buildings, road construction, tunnels, pipe lines, power lines etc. The application of geophysical methods especially seismic and electrical have been the most effective methods in providing information on the geological structure, soil properties and hydrological conditions of the subsurface which play a prime role in determining the stability of the surface of the soil [3]. Several of the geophysical methods; seismic, electrical, magnetic and gravimetric methods, originally developed for mineral and oil prospecting have been successfully adopted for geotechnical engineering application and are now being used increasingly [4]. Geophysical methods have been used extensively in dam site investigations ([5]; [6]; [7]; [8]; [9]; [10]; [11]; [12]). Geoelectric surveys, particularly resistivity measurements, still account for a large amount of work in using geophysical methods for surveys of shallow depths. The advantage is that they are not so demanding for instrumentation. Already a dam constructed near the study area dried up. The major cause of the dam failure in the study area of this work has not been established or recorded by any writer or engineer. Most of the investigations carried out within the area in the past were normal surface site investigations. Little or no notice was given to the geological conditions of the subsoils or to the manner in which they were placed or compacted. There is thus need to do a thorough sub-surface investigation prior to any further design. From information gathered, Okputong Bende and Amaeke Abam residents have been at log-ahead over Idonyi river due to its insufficient water supply especially during dry season and being the only avaliable river between the two communities. Thus constructing a suitable dam may bring unity and peace between the two villages, for it will still supply water during dry season. There is a failed dam beside the river which was constructed locally, but did not last up to two years and failed due to unknown reasons. Therefore, the need to carry out a geophysical study of the failed dam area, through geoelectrical characterization of rock units, becomes very important. This will not only provide subsurface information likely to reveal the cause of the failure but will also enable the contractor adopt a corrective measure for a lasting reconstruction work. Again, cost-effective proposal may be made rather than discovering causes after work has reached advanced stage, leading to variations that result in abandoned projects. This informed the present study.

\section{Location of the Study Area}

Idonyi River is in Amaeke Abam / Bende area at about $5 \mathrm{~km}$ east of Bende or about $35 \mathrm{~km}$ southwest of Abiriba. It covers an area of approximately $90 \mathrm{sqkm}$. The study area has the following coordinates: latitudes $5^{\circ} 33^{1} \mathrm{~N}$ and $5^{\circ}$ $51^{1} \mathrm{~N}$ and longitudes $7^{0} 34^{1} \mathrm{E}$ and $7^{0} 42^{1} \mathrm{E}$. This is shown in the topographic map of the study area below (Figure 1). The area is not remote, yet under-developed, although some basic amenities such as electricity, telephone facilities and 
road network are in place. There is fertile land in the area. Crops such as lemon, maize, cassava, yam, rice and cocoa

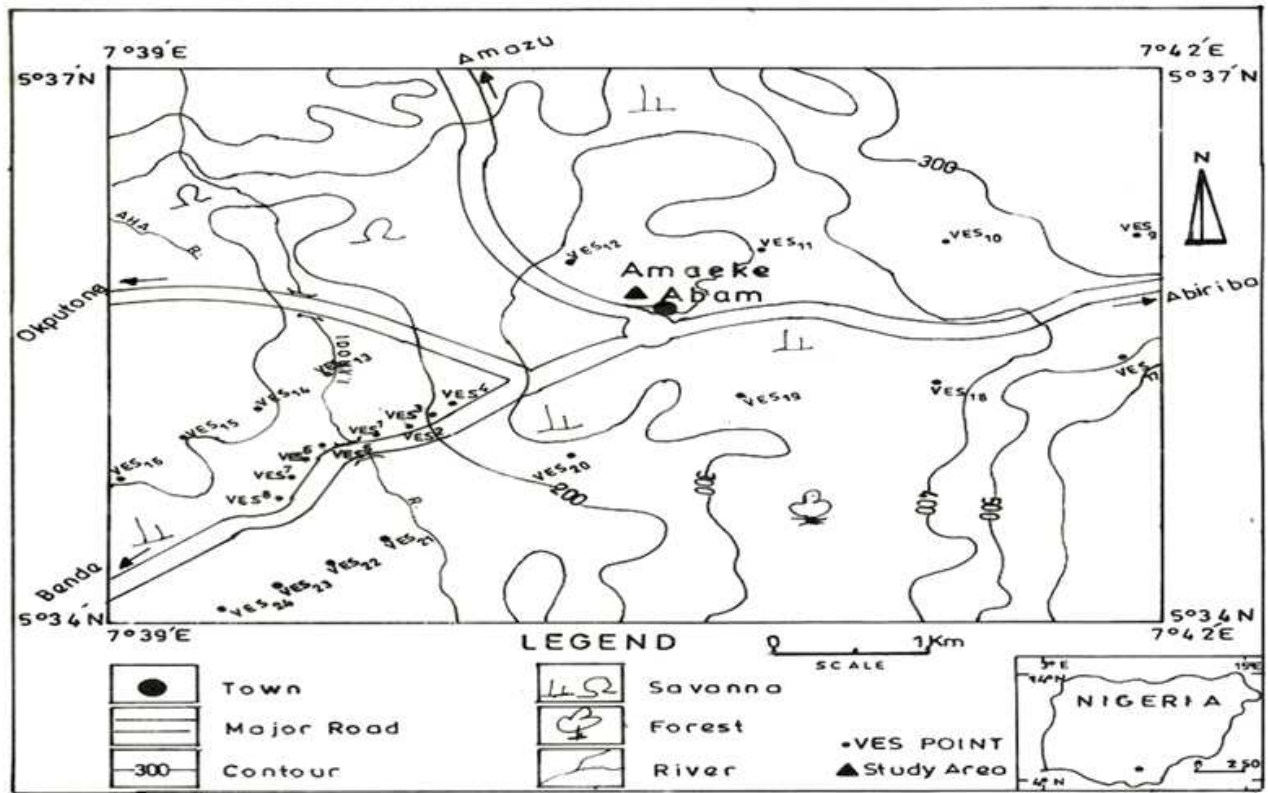

Figure 1. Topographic map of study area showing VES points

\section{Objectives of the Study}

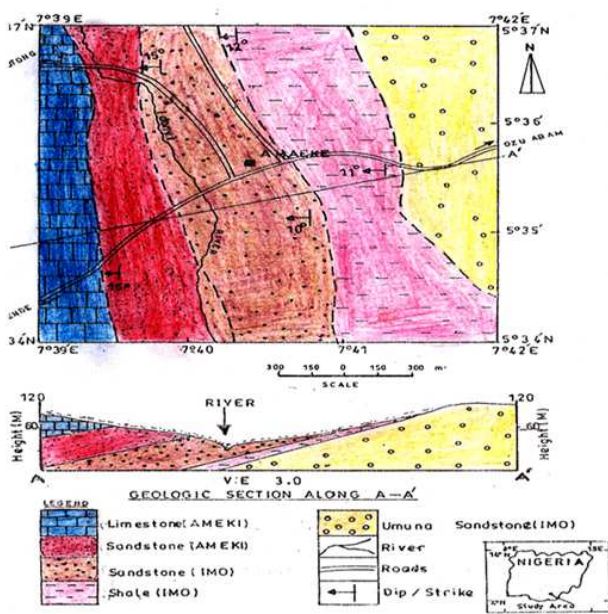

Figure 2. Geological Map of the study area showing the NNW-SSE flowing Idonyi River

The research is aimed at using geoelectrical technique to assess the subsurface conditions to depths that would signfinicantly influence the type of failure observed on the failed dam, using these techniques to study among other things, the rock type/structures, topography of the area, surface and ground water conditions and their probable contributions to the cause of the failed dam. Based on the findings, the project is also intended to offer suggestions that will ensure reliable design and subsequent construction of a dam across the Idonyi river. Such recommendations would also be useful to the Federal Ministry of Works And Housing Nigeria and its contractors in their future engineering works especially in the anticipated rehabilitation of the failed dam near Idonyi river. Geologically, two major Formations are observable in the area. These are the Eocene Ameki and the Tertiary Imo Formations (Figure 2).

\section{Geophysical Study}

With the use of the electrical method one would be able to know the conductivity (or its inverse, resistivity) of the subsurface. The subsurface is probed by the passage of electric current (DC) into the earth with the following determinants: (i) average number of geoelectric layers (ii) the vertical changes in the resistivity of the subsurface layers and the depth to the discontinuous horizons (iii) Possible rock types and productive potentials of suitable aquifers and their lithological characteristics. Geophysical methods themselves will not discover groundwater, soil type or mineral deposits; they indicate presence of these substances. A drill hole must always be put down to make the actual confirmation. However, the principle behind the use of resistivity lies on the fact that any subsurface variation in conductivity alters the form of current flow within the earth and this in turn affects the distribution of electric potential. The usual practice in resistivity surveying technique is to pass current through electrodes and to measure potential drop through a second pair of electrodes called potential electrode (Figure 3 ). Thus, it is possible to search for anomalies in an otherwise stationary current electric fields established in the ground by the introduction of a direct current with which to delineate the boundaries between rock units and rock strata of different water content through the observation of large contrast in resistivity between boundaries or strata [13]. 5-20mA 
current passed through the current electrodes, the measuring instrument has the important feature of measuring the resistance value $(\mathrm{R})$ which is $\mathrm{V} / \mathrm{I}$ according to Ohm's law (V=IR) where $\mathrm{V}$ is the potential difference.

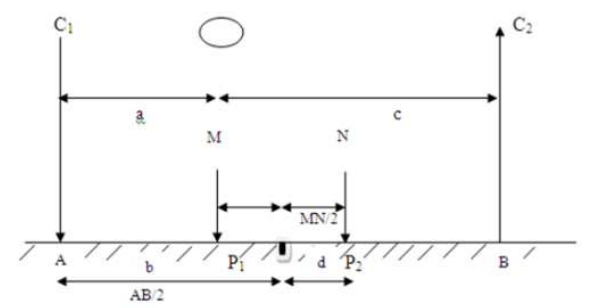

Figure 3. Sketch of four electrodes Schlumberger configuration.

Resistance (R) is a property of the path followed by the current. $R$ is related to the resistivity $(\rho)$ through both the path length $\mathrm{L}$ and the cross sectional area $(\mathrm{A})$, through which the current flows.

That is,

$$
\mathrm{R}=\rho \mathrm{L} / \mathrm{A}
$$

$\rho=$ Resistivity $(\Omega \mathrm{m}), \mathrm{L}=$ Path Length $(\mathrm{m}), \mathrm{A}=$ CrossSectional area $\left(\mathrm{m}^{2}\right), \mathrm{R}=$ Resistance $(\Omega)$

$$
\begin{aligned}
& \rho=\mathrm{RA} / \mathrm{L} \\
& \mathrm{R}=\mathrm{V} / \mathrm{I}
\end{aligned}
$$

Considering the potential difference $\mathrm{V}$ and the current in the resistivity measurement, the direct currents (dc) are introduced into the ground through two points electrodes $C_{1}$ and $\mathrm{C}_{2}$ (Figure 3 above), and the resulting potential difference measured between the point electrodes $\mathrm{P}_{1}$ and $\mathrm{P}_{2}$.

The current at $\mathrm{C}_{1}$ is positive while current at $\mathrm{C}_{2}$ is negative (return current). For a standard measurement circuit, the potentials at $\mathrm{P}_{1}$ is the superposition of the potentials due to current sources at $C_{1}$ and $C_{2}$ [14]. Similarly, the potentials at $\mathrm{P}_{2}$ is the superposition of the potential due to current at $\mathrm{C}_{1}$ and $\mathrm{C}_{2}$. The potential at $\mathrm{P}_{1}$ is:

$$
\mathrm{VP}_{1}=\frac{1 \rho}{2 \pi}\left(\begin{array}{lr}
\underline{1} & -\frac{1}{\mathrm{a}} \\
\mathrm{c}
\end{array}\right)
$$

And potential at $\mathrm{P}_{2}$ is:

$$
\mathrm{VP}_{2}=\frac{1 \rho}{2 \pi}\left(\frac{1}{\mathrm{~b}}-\frac{1}{\mathrm{~d}}\right)
$$

And the potential difference between $\mathrm{P}_{1}$ and $\mathrm{P}_{2}$ is given as

$$
\begin{gathered}
\Delta V=\frac{1 \rho}{2 \pi}\left\{\left(\frac{1}{a}-\frac{1}{c}\right)-\left(\frac{1}{a}-\frac{1}{c}\right)\right\} \\
\rho=\left(\frac{2 \pi \Delta V}{1}\right)\left\{\left(\frac{1}{a}-\frac{1}{c}\right)-\left(\underline{b}-\frac{1}{b}\right)\right\} \\
\rho=\underline{2 \pi \Delta V}
\end{gathered}
$$

Where $G=\left\{\left[\frac{1}{a}-\frac{1}{c}\right)-\left(\frac{1}{b}-\frac{1}{d}\right)\right\}$

The factor $\frac{2 \pi}{G}$ is called Geometric factor,

It is a function of the electrode spacing.

The resistivity $\rho=\frac{2 \pi \Delta v}{\text { GI }}$ of the earth is that for which the ground is homogenous and isotropic. But the ground in real practice is inhomogeneous. Therefore, an apparent resistivity $\rho_{\mathrm{a}}$ is used.

$$
\therefore \rho_{\mathrm{a}}=\frac{2 \pi \Delta \mathrm{V}}{\mathrm{GI}}
$$

But $\frac{\Delta v}{I}=R$

$$
\therefore \rho_{\mathrm{a}}=\frac{2 \pi \mathrm{R}}{\mathrm{G}}
$$

Or

$$
\rho_{\mathrm{a}}=\mathrm{KR}
$$

Where $\mathrm{K}=\frac{2 \pi}{\mathrm{G}}$

$$
\mathrm{K}=\left(\underline{\mathrm{a}}^{2}-\frac{\mathrm{b}}{\mathrm{b}}\right) \pi
$$

Using these formulae above (equations $11 \& 12$ ), the apparent resistivity value for each electrode separation is calculated using the resistance value displayed by the measuring instrument (Terrameter) and the schlumberger geometric factor $\mathrm{K}=\left(\mathrm{a}^{2} / \mathrm{b}-\mathrm{b} / 4\right) \pi$. Conduction of electricity in the ground occurs through the interstitial fluid (or water) which is usually present in the rock and invariably contains some dissolved salt. The chemistry of the fluid in the pores spaces of rocks matters as it determines whether the rock will be conductive or not. Low resistivity value usually indicates the presence of water (or shale) in the formation [15]. The clay minerals have high cations exchanged and would thus act as if a fluid of high conductivity is present in the pore spaces of the rock. Shales have generally low resistivity values. The resistivity is lower if they are wet. The resistivity of a wet formation and a dry formation of the same rock may differ by factor of up to ten [15]. Wet shale layers/lenses have a resistivity in the range of $0-20$ ohm-meters $(\Omega \mathrm{m})$. Sandstone saturated with fresh water has a resistivity range of about $30-100 \Omega \mathrm{m}$. This can be reduced in the presence of specific shale but can increase many times, if the sandstone is dry [3]. The range of resistivities among rocks and rock formations is enormous extending form $10^{-5}$ to $10^{15} \Omega \mathrm{m}[16]$. Rocks and minerals with resistivities from $10^{-5}-10^{-1} \Omega \mathrm{m}$ are considered good conductors, those from $1-10^{7} \Omega \mathrm{m}$ intermediate conductors and those from $10^{8}-10^{15} \Omega \mathrm{m}$ poor conductors. Resistivities of rock formations vary over a wide range depending on the material, density, porosity, pore size and shape, water content, salinity and temperature. 


\section{Materials and Methods}

\subsection{Field Procedures}

The materials and methods employed in acquiring field data are discussed. The field procedures, instrumentation, data acquisition techniques and data reduction are presented. The investigation commenced with a preliminary site visit of the study area in August 2010. The visit was intended to critically observe the general environmental, geographic settings and the climatic conditions of the study area. The Community heads were also informed of our research and plans for actual field work made.

\subsection{Geophysical Method}

In this study, electrical resistivity method was used. The method was preferred to the other geophysical prospecting techniques such as seismic, magnetic, gravimetric because it is more economical. Besides, it is equally appropriate for use to obtain details about location, depth and resistivity of subsurface formations, at close thickness of $0-1,0-5$ or 0 $-20 \mathrm{~m}$. The survey was carried out with ABEM Terrameter model SAS 1000C. The usual experimental field set-up based on four electrode spacing was adopted. The soundings were laid out in three (3) profiles; eight (8) VES on each profile. A total of twenty-four (24) VES data were conducted. The Schlumberger electrode configuration was adopted to a total spread length of 110 meters $(\mathrm{AB} / 2$ of 55 meters). The field procedure consisted of expanding $A B$

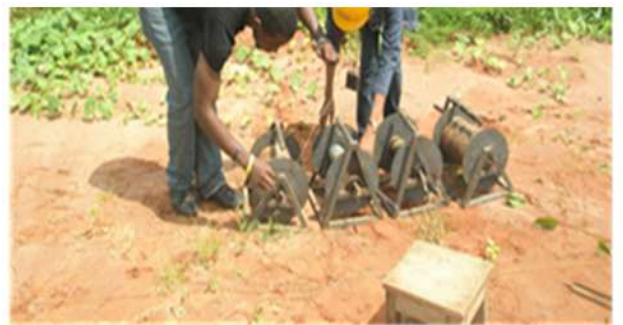

Plate 1. Field Layout while MN was fixed for increasing mode (Plate 1). The process yielded a rapidly increasing penetration of current into the subsurface and decreasing potential difference across $\mathrm{MN}$. Although $\mathrm{MN}$ was fixed while $\mathrm{AB}$ was being expanded, when the measuring capability of the instrument was low, a new value for $\mathrm{MN}$ was used about 2 to 4 times lesser than the preceding value and the survey was continued. Caution was taken to keep track of which reel corresponding to electrodes $\mathrm{A}, \mathrm{B}, \mathrm{M}$, and $\mathrm{N}$ by colouring the wires with black, blue, red and yellow for the respective electrodes. The aim was to ensure proper connections. The results would be incorrect if the cables were not hooked up appropriately to the electrodes. Straight profiles were ensured (Plate 2). Equations 11 and 12 above were followed. The product of the resistance and the geometric factor $\mathrm{K}$ gave a succession of apparent resistivity values. The sounding curve for each sounding station was obtained by plotting the apparent resistivity values on the coordinate and half electrode spacing $\mathrm{AB} / 2$ or $\mathrm{L} / 2$ on the abscissa on a bilogarithmic graph paper. A qualitative estimate of the relationship between electrode spacing and the depth of penetration was made using curve matching technique. Quantitative results were obtained with computer modeling technique using the Zohdy software [17]. The parameters such as apparent resistivity and half electrode spacing were used as input data for the Computer modeling. The relationship between $\mathrm{MN} / 2$ and $\mathrm{AB} / 2$ or $\mathrm{L} / 2$ was converted into a relationship between apparent resistivity $\rho_{\mathrm{a}}$ and actual depth penetration by the computer.

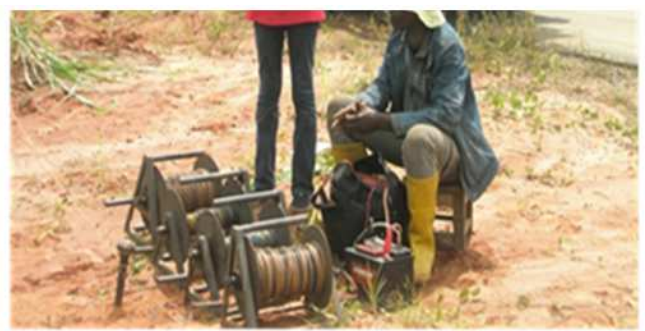

Plate 2. VES Data Collection

\section{Results and Discussions}

The VES field data for all the stations were fed into the Zohdy software and the modeled curves were obtained. Table 1 gives the inferred interpretation of the geoelectric section.

Table 1. Layer-wise Interpretation of the VES data

\begin{tabular}{|c|c|c|c|c|c|c|c|c|c|c|c|c|c|c|c|}
\hline \multirow{3}{*}{$\begin{array}{l}\text { VES } \\
\text { NO }\end{array}$} & \multicolumn{15}{|c|}{ LAYER PARAMETERS } \\
\hline & \multicolumn{3}{|c|}{ LAYER 1} & \multicolumn{3}{|c|}{ LAYER 2} & \multicolumn{3}{|c|}{ LAYER 3} & \multicolumn{3}{|c|}{ LAYER4 } & \multicolumn{3}{|c|}{ LAYER 5} \\
\hline & $\begin{array}{l}\text { Dept } \\
\text { h } \\
(\mathrm{m})\end{array}$ & $\begin{array}{l}\rho(\mathrm{Oh} \\
\mathrm{m}-\mathrm{m})\end{array}$ & $\begin{array}{l}\text { Litholo } \\
\text { gy }\end{array}$ & $\begin{array}{l}\text { Dept } \\
\mathrm{h} \\
(\mathrm{m})\end{array}$ & $\begin{array}{l}\rho(\mathrm{Oh} \\
\mathrm{m}-\mathrm{m})\end{array}$ & $\begin{array}{l}\text { Litholo } \\
\text { gy }\end{array}$ & $\begin{array}{l}\text { Dept } \\
\text { h } \\
(\mathrm{m})\end{array}$ & $\begin{array}{l}\rho(\mathrm{Oh} \\
\mathrm{m}-\mathrm{m})\end{array}$ & $\begin{array}{l}\text { Litholo } \\
\text { gy }\end{array}$ & $\begin{array}{l}\text { Dept } \\
\mathrm{h} \\
(\mathrm{m})\end{array}$ & $\begin{array}{l}\rho(\mathrm{Oh} \\
\mathrm{m}-\mathrm{m})\end{array}$ & $\begin{array}{l}\text { Litholo } \\
\text { gy }\end{array}$ & $\begin{array}{l}\text { Dept } \\
\mathrm{h} \\
(\mathrm{m})\end{array}$ & $\begin{array}{l}\mathrm{P} \\
(\mathrm{Ohm} \\
-\mathrm{m})\end{array}$ & $\begin{array}{l}\text { Lith } \\
\text { olog } \\
\mathrm{y}\end{array}$ \\
\hline $\begin{array}{l}\text { VES } \\
1\end{array}$ & 1.0 & 306 & Topsoil & 2.0 & 216 & $\begin{array}{l}\text { Shaly } \\
\text { limesto } \\
\text { ne }\end{array}$ & 5.8 & 1430 & Sand & 19.3 & 69.2 & $\begin{array}{l}\text { Mudsto } \\
\text { ne }\end{array}$ & $>50$ & 1000 & $\begin{array}{l}\text { San } \\
\text { d }\end{array}$ \\
\hline $\begin{array}{l}\text { VES } \\
2\end{array}$ & 1.0 & 649 & Topsoil & 1.7 & 409 & $\begin{array}{l}\text { Shaly } \\
\text { limesto } \\
\text { ne }\end{array}$ & 11.3 & 2840 & Sand & 23.3 & 92 & $\begin{array}{l}\text { Mudsto } \\
\text { ne }\end{array}$ & $>30$ & 704 & $\begin{array}{l}\text { San } \\
\text { d }\end{array}$ \\
\hline
\end{tabular}




\begin{tabular}{|c|c|c|c|c|c|c|c|c|c|c|c|c|c|c|c|}
\hline \multirow{3}{*}{$\begin{array}{l}\text { VES } \\
\text { NO } \\
\text { VES } \\
3\end{array}$} & \multicolumn{15}{|c|}{ LAYER PARAMETERS } \\
\hline & \multicolumn{3}{|c|}{ LAYER 1} & \multicolumn{3}{|c|}{ LAYER 2} & \multicolumn{3}{|c|}{ LAYER 3} & \multicolumn{3}{|c|}{ LAYER4 } & \multicolumn{3}{|c|}{ LAYER 5} \\
\hline & 0.9 & 1580 & Topsoil & 3.4 & 810 & $\begin{array}{l}\text { Iron- } \\
\text { stained } \\
\text { sand }\end{array}$ & 6.7 & 2380 & $\begin{array}{l}\text { Mudsto } \\
\text { ne }\end{array}$ & 38.2 & 496 & Sand & $>30$ & 587 & $\begin{array}{l}\text { San } \\
\text { d }\end{array}$ \\
\hline $\begin{array}{l}\text { VES } \\
4\end{array}$ & 2.2 & 2700 & $\begin{array}{l}\text { Iron- } \\
\text { stained } \\
\text { sand }\end{array}$ & 7.3 & 661 & $\begin{array}{l}\text { Shaly } \\
\text { limesto } \\
\text { ne }\end{array}$ & 21.3 & 186 & $\begin{array}{l}\text { Shaly } \\
\text { sand }\end{array}$ & $>35$ & 3810 & $\begin{array}{l}\text { Mudsto } \\
\text { ne }\end{array}$ & - & - & - \\
\hline $\begin{array}{l}\text { VES } \\
5\end{array}$ & 0.9 & 1100 & Topsoil & 1.5 & 556 & $\begin{array}{l}\text { Shaly } \\
\text { limesto } \\
\text { ne }\end{array}$ & 7.4 & 234 & $\begin{array}{l}\text { Mudsto } \\
\text { ne }\end{array}$ & 29.4 & 39.8 & Shale & $>50$ & 28.8 & $\begin{array}{l}\text { San } \\
\text { d }\end{array}$ \\
\hline $\begin{array}{l}\text { VES } \\
6\end{array}$ & 1.0 & 272 & Topsoil & 1.9 & 234 & $\begin{array}{l}\text { Shaly } \\
\text { limesto } \\
\text { ne }\end{array}$ & 11.3 & 34.3 & $\begin{array}{l}\text { Shaly } \\
\text { sand }\end{array}$ & 43.6 & 43.6 & Shale & $>50$ & 65.9 & $\begin{array}{l}\text { Shal } \\
\text { e }\end{array}$ \\
\hline $\begin{array}{l}\text { VES } \\
7\end{array}$ & 0.8 & 655 & Topsoil & 2.3 & 31.6 & $\begin{array}{l}\text { Shaly } \\
\text { limesto } \\
\text { ne }\end{array}$ & 4.3 & 36.7 & Shaly & 10.1 & 2.3 & $\begin{array}{l}\text { Shale } \\
\text { stone }\end{array}$ & $>35$ & 380 & $\begin{array}{l}\text { Shal } \\
\text { e }\end{array}$ \\
\hline $\begin{array}{l}\text { VES } \\
8\end{array}$ & 0.8 & 677 & Topsoil & 4.4 & 34 & $\begin{array}{l}\text { Iron- } \\
\text { stained } \\
\text { sand }\end{array}$ & 9.4 & 2.0 & Sand & $>50$ & 280 & & - & - & - \\
\hline $\begin{array}{l}\text { VES } \\
9\end{array}$ & 2.1 & 2570 & $\begin{array}{l}\text { Lateritic } \\
\text { soil }\end{array}$ & 14.3 & 910 & $\begin{array}{l}\text { Iron- } \\
\text { stained } \\
\text { sand }\end{array}$ & $>35$ & 396 & Sand & - & - & - & - & - & - \\
\hline $\begin{array}{l}\text { VES } \\
10\end{array}$ & 3.0 & 1250 & $\begin{array}{l}\text { Lateritic } \\
\text { soil }\end{array}$ & 14.8 & 1150 & $\begin{array}{l}\text { Iron- } \\
\text { stained } \\
\text { sand }\end{array}$ & $>35$ & 484 & Sand & - & - & - & - & - & - \\
\hline $\begin{array}{l}\text { VES } \\
11\end{array}$ & 1.8 & 602 & $\begin{array}{l}\text { Lateritic } \\
\text { soil }\end{array}$ & 9.8 & 3260 & $\begin{array}{l}\text { Iron- } \\
\text { stained } \\
\text { sand }\end{array}$ & $>35$ & 426 & Sand & - & - & - & - & - & - \\
\hline $\begin{array}{l}\text { VES } \\
12\end{array}$ & 2.4 & 303 & $\begin{array}{l}\text { Lateritic } \\
\text { soil4.82 } \\
73\end{array}$ & 6.5 & 1520 & $\begin{array}{l}\text { Iron- } \\
\text { stained } \\
\text { sand }\end{array}$ & $>35$ & 187 & Sand & - & - & - & - & - & - \\
\hline $\begin{array}{l}\text { VES } \\
13\end{array}$ & 1.5 & 970 & $\begin{array}{l}\text { Lateritic } \\
\text { soil }\end{array}$ & 4.8 & 273 & $\begin{array}{l}\text { Mudsto } \\
\text { ne }\end{array}$ & 22.8 & 80 & Shale & $>35$ & 38.8 & Shale & - & - & - \\
\hline $\begin{array}{l}\text { VES } \\
14\end{array}$ & 1.7 & 275 & $\begin{array}{l}\text { Lateritic } \\
\text { soil }\end{array}$ & 4.8 & 105 & Shale & 12.4 & 296 & $\begin{array}{l}\text { Clayey } \\
\text { sand }\end{array}$ & $>35$ & 253 & Shale & - & - & - \\
\hline $\begin{array}{l}\text { VES } \\
15\end{array}$ & 1.0 & 511 & $\begin{array}{l}\text { Lateritic } \\
\text { soil }\end{array}$ & 25.4 & 23.5 & Shale & $>35$ & 10.1 & Shale & - & - & - & - & - & - \\
\hline $\begin{array}{l}\text { VES } \\
16\end{array}$ & 0.9 & 1580 & $\begin{array}{l}\text { Lateritic } \\
\text { soil }\end{array}$ & 20.7 & 81 & Shale & $>35$ & 59.9 & Shale & - & - & - & - & - & - \\
\hline $\begin{array}{l}\text { VES } \\
17\end{array}$ & 2.2 & 2530 & $\begin{array}{l}\text { Lateritic } \\
\text { soil }\end{array}$ & 8.0 & 694 & $\begin{array}{l}\text { Iron- } \\
\text { stained } \\
\text { sand }\end{array}$ & $>35$ & 407 & Sand & - & - & - & - & - & - \\
\hline $\begin{array}{l}\text { VES } \\
18\end{array}$ & 0.9 & 1390 & $\begin{array}{l}\text { Lateritic } \\
\text { soil }\end{array}$ & 12.3 & 1070 & $\begin{array}{l}\text { Iron- } \\
\text { stained } \\
\text { sand }\end{array}$ & 22 & 720 & $\begin{array}{l}\text { Mudsto } \\
\text { ne }\end{array}$ & $>35$ & 363 & Sand & - & - & - \\
\hline $\begin{array}{l}\text { VES } \\
19\end{array}$ & 2.0 & 587 & $\begin{array}{l}\text { Lateritic } \\
\text { soil }\end{array}$ & 7.3 & 3920 & $\begin{array}{l}\text { Mudsto } \\
\text { ne }\end{array}$ & $>35$ & 424 & Shale & - & - & - & - & - & - \\
\hline $\begin{array}{l}\text { VES } \\
20\end{array}$ & 2.3 & 325 & Topsoil & 7.3 & 1300 & $\begin{array}{l}\text { Lateriti } \\
\text { c soil }\end{array}$ & 17.9 & 66.8 & $\begin{array}{l}\text { Mudsto } \\
\text { ne }\end{array}$ & $>35$ & 531 & Sand & - & - & - \\
\hline $\begin{array}{l}\text { VES } \\
21\end{array}$ & 1.6 & 1000 & $\begin{array}{l}\text { Mudsto } \\
\text { ne }\end{array}$ & 7.2 & 288 & $\begin{array}{l}\text { Lateriti } \\
\text { c soil }\end{array}$ & $>35$ & 41 & Shale & - & 38.8 & - & - & - & - \\
\hline $\begin{array}{l}\text { VES } \\
22\end{array}$ & 1.6 & 287 & $\begin{array}{l}\text { Mudsto } \\
\text { ne }\end{array}$ & 5.4 & 67.6 & Shale & 16.2 & 35.9 & Shale & $>35$ & 114 & $\begin{array}{l}\text { Shaly } \\
\text { sand }\end{array}$ & - & - & - \\
\hline $\begin{array}{l}\text { VES } \\
23\end{array}$ & 1.0 & 536 & $\begin{array}{l}\text { Mudsto } \\
\text { ne }\end{array}$ & 22.7 & 20.8 & Shale & $>35$ & 8.8 & Shale & - & - & - & - & - & - \\
\hline $\begin{array}{l}\text { VES } \\
24\end{array}$ & 1.0 & 900 & $\begin{array}{l}\text { Mudsto } \\
\text { ne }\end{array}$ & 8.7 & 57.8 & $\begin{array}{l}\text { Sandy } \\
\text { shale }\end{array}$ & 22.9 & 157 & $\begin{array}{l}\text { Sandy } \\
\text { shale }\end{array}$ & $>35$ & 24.5 & Shale & - & - & - \\
\hline
\end{tabular}



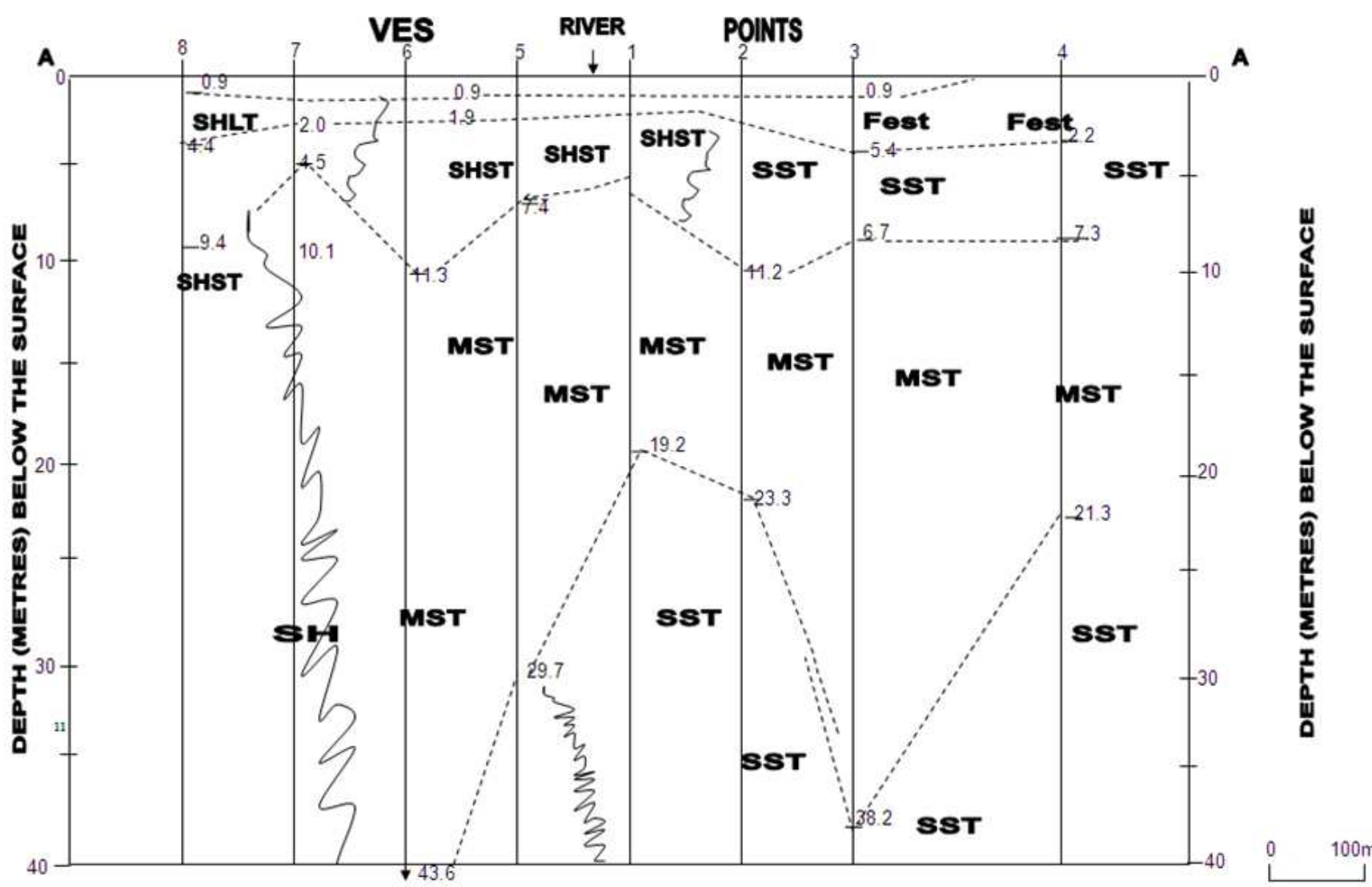

Figure 4. Geoelectric Section Along A-Al Profile (VES 1-8)

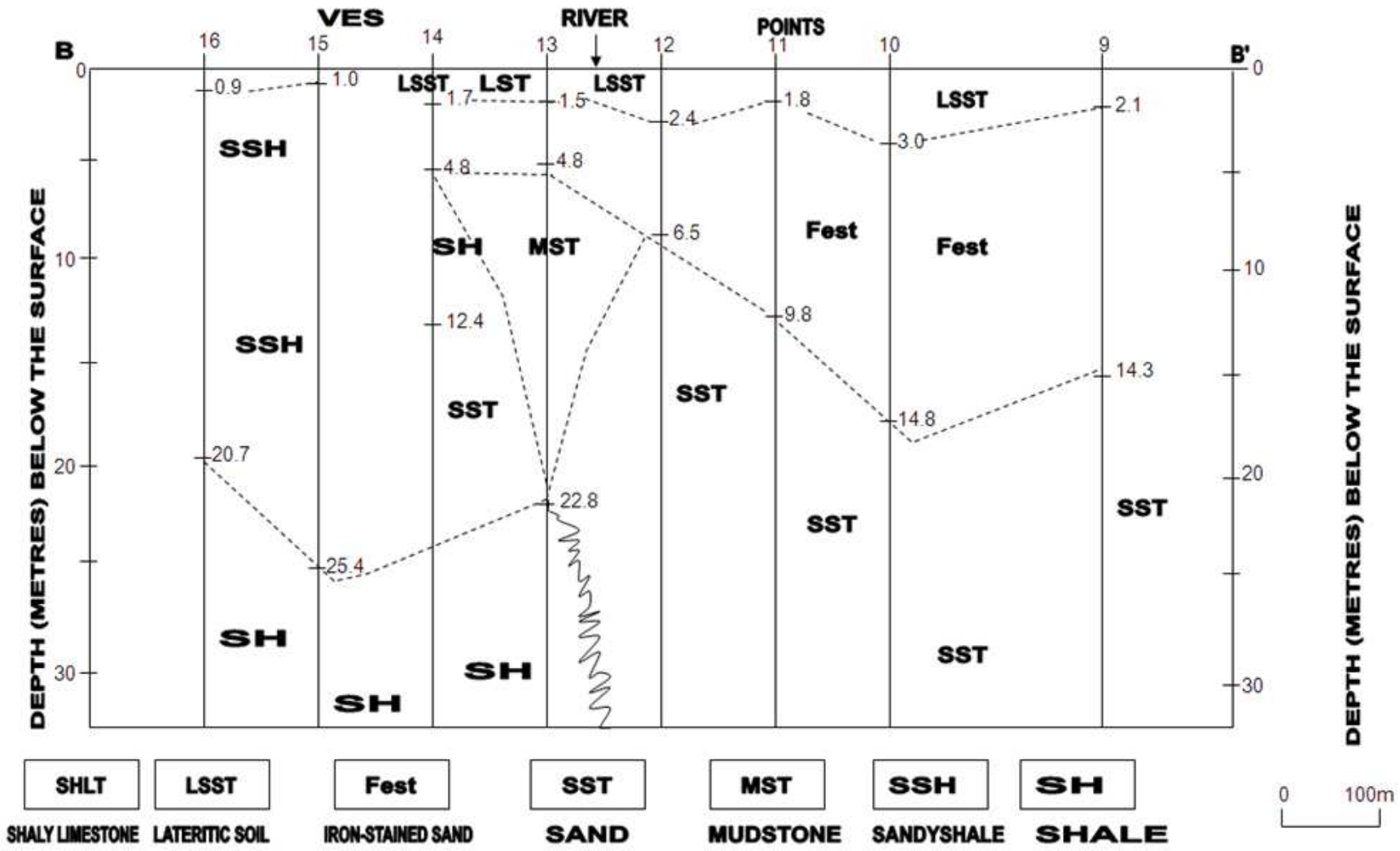

Figure 5. Geoelectric Section Along B-B Profile (VES 9-16) 


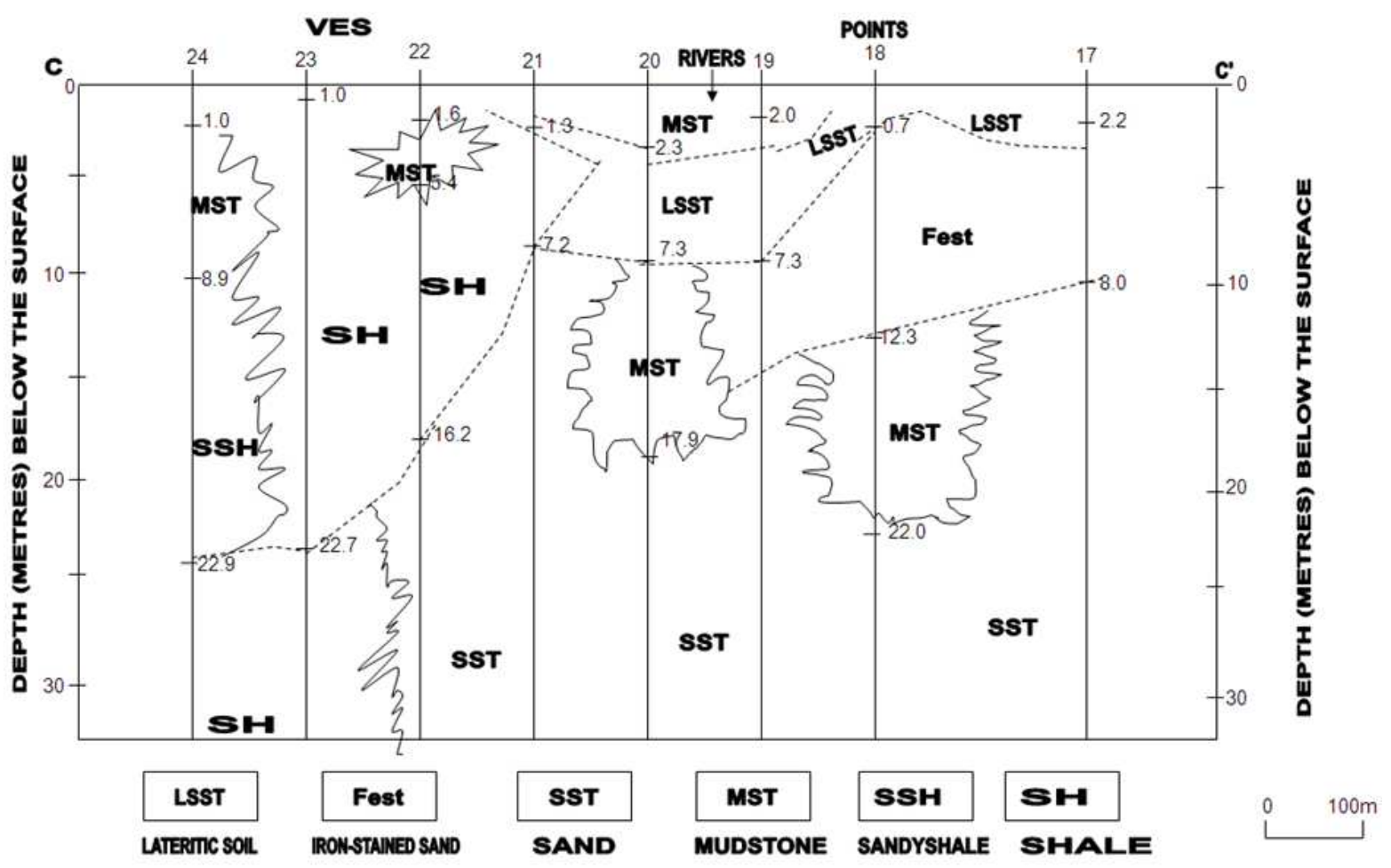

Figure 6. Geoelectric Section Along $C-C^{l}$ Profile (VES 17-24)

Interpreted data from the twenty-four (24) electrical resistivity sounding results carried out around the study area were used to generate geoelectric sections for correlation. This correlation was done along three profiles $\mathrm{AA}^{1}, \mathrm{BB}^{1}$ and $\mathrm{CC}^{1}$ (Figures 4, 5 and 6).

Profile $\mathrm{A}-\mathrm{A}^{1}$ : This profile is $3 \mathrm{~km}$ long and appears at the centre (west - east) of the study area. This displays about five (5) distinct litho-units with sand layer at the base having resistivity ranging from $587 \Omega \mathrm{m}$ to $1000 \Omega \mathrm{m}$; this is overlain by litho-unit modeled as mudstone with resistivity range of $2 \Omega \mathrm{m}-238 \Omega \mathrm{m}$. Overlying the mudstone layer is the unit modeled as sand unit with resistivity ranging from $216 \Omega \mathrm{m}$ to slightly over $810 \Omega \mathrm{m}$ at the eastern end and shaly sand unit of range $31.6 \Omega \mathrm{m}-556 \Omega \mathrm{m}$ at the western end. This is overlain by iron-stained sand layer at the eastern end having resistivity range of $306 \Omega \mathrm{m}-2700 \Omega \mathrm{m}$ and shaly layer at the western end having resistivity range of $28 \Omega \mathrm{m}-380 \Omega \mathrm{m}$. The sand layer which is the base was resolved in the study (Figure 4).

Profile $\mathrm{B}-\mathrm{B}^{1}$ : This profile is $8 \mathrm{~km}$ long and situated at North of the study area. This section displays about three (3) litho-units with the sand layer at the base. This has resistivity range of $187 \Omega \mathrm{m}-3260 \Omega \mathrm{m}$ at the eastern end and shale at the western end with resistivity range of $10.1 \Omega \mathrm{m}-59.9 \Omega \mathrm{m}$. Overlying the sand unit, is the shaly sand unit with resistivity range of $23.5 \Omega \mathrm{m}-273 \Omega \mathrm{m}$; the shaly sand layer is overlain by the unit modeled as lateritic soil layer with resistivity range of $30 \Omega \mathrm{m}-2570 \Omega \mathrm{m}$. The sand layer which is the base was resolved in the study (Figure 5).

Profile $\mathrm{C}-\mathrm{C}^{1}$ : The profile is $7 \mathrm{~km}$ long and is South of Bende - Abam road. The section displays three (3) litho- units with sand unit at the base having resistivity value ranging from $66.8 \Omega \mathrm{m}-720 \Omega \mathrm{m}$ at the eastern end and shale at the western end with resistivity range of $8.8 \Omega \mathrm{m}-157 \Omega \mathrm{m}$. This is overlain by iron-stained sand at the eastern end with resistivity range of $694 \Omega \mathrm{m}-3920 \Omega \mathrm{m}$ and shaly sand at the western end with resistivity range of $20.8 \Omega \mathrm{m}-288 \Omega \mathrm{m}$. Overlying this litho-unit is the unit modeled as lateritic soil layer at the eastern end with resistivity range of $287 \Omega \mathrm{m}$ $1000 \Omega \mathrm{m}$ and mudstone layer at the western end with resistivity range of $325 \Omega \mathrm{m}-2530 \Omega \mathrm{m}$. The base unit which is sand was resolved in the study (Figure 6).

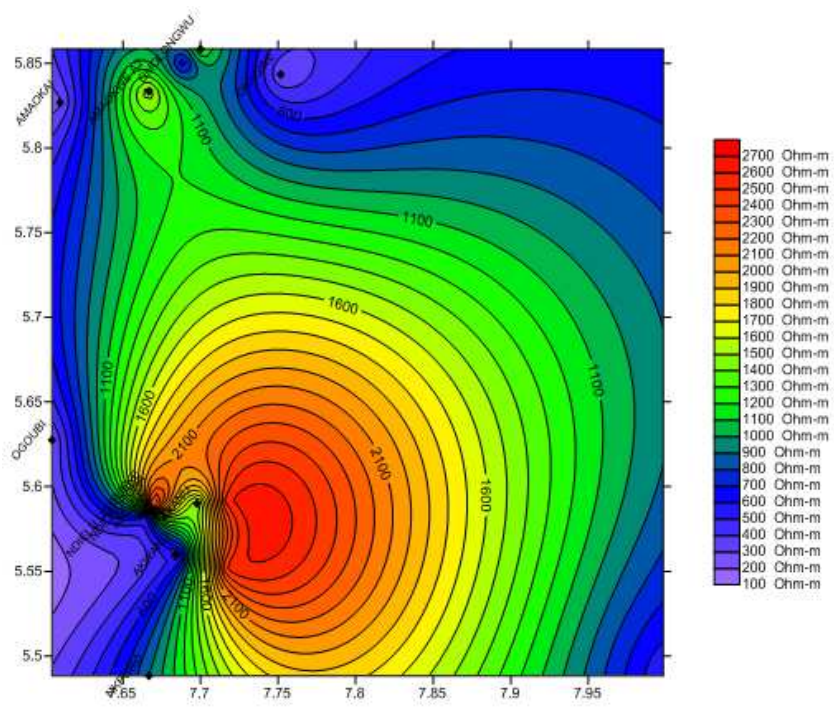

Figure 7. Iso-resistivity Image Map at AB/2 $=4.5 \mathrm{~m}$ (approximately $3 \mathrm{~m}$ depth probed) 


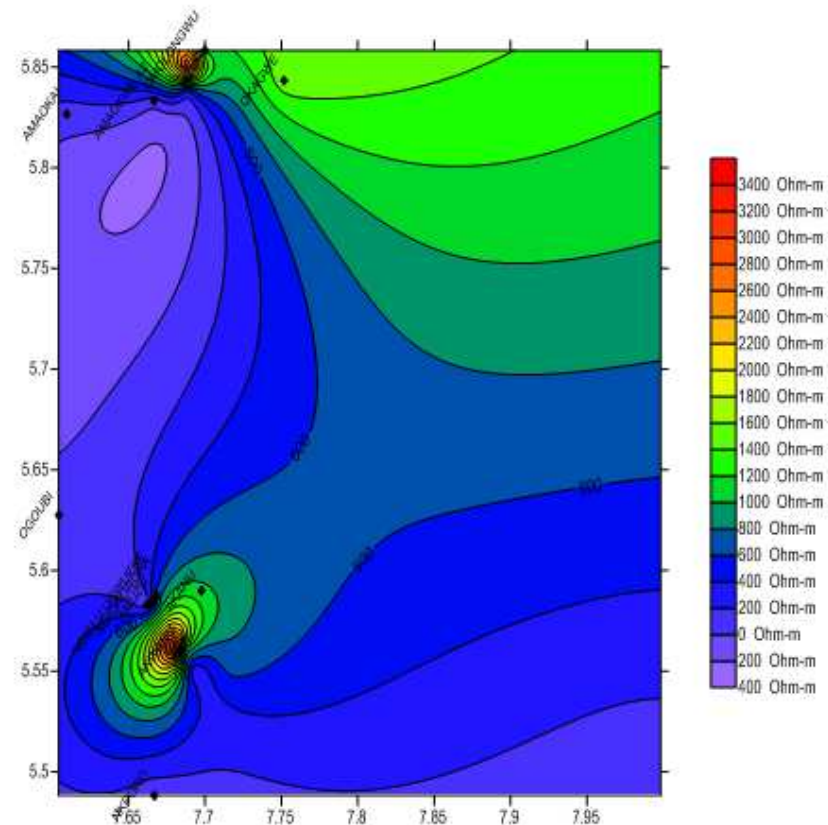

Figure 8. Iso-resistivity Image Map at AB/2 $=12 \mathrm{~m}$ (approximately $8 \mathrm{~m}$ depth probed)

The Isoresistivity map for $\mathrm{AB} / 2=4.5 \mathrm{~m}$ shown in Figure 7 above displays that the western part of the study area has low resistivity values ranging from 100-900 ohm-meters. This corresponds to west of the river that is being underlain by relatively low resistive materials (shales-mudstonelimestone sequence typical of Ameki Formation). The eastern part of the area (east of the Idonyi River) displays high resistivity values ranging from 1000-2700 ohm-meters. This corresponds to the Umuna sandstone unit of the Tertiary Imo Formation exposed at this vicinity. The northern and southeastern fringes of the area show low resistivity values ranging from 100-900 ohm-meters typifying exposures of Imo Formation within the locality. The resistivity of the study area at this spacing with the effective depth of approximately $3 \mathrm{~m}$ delineated favourably the two main geologic units viz: the Imo Formation to the east and the Ameki Formation to the western part of the area. The Isoresistivity map for $\mathrm{AB} / 2=12 \mathrm{~m}$ shown in Figure 8 above displays low resistivity values at the western and southern parts of the area with values ranging from 400-800 ohm-meter. The northern and northeastern parts indicate moderate resistivity values of the order of 1000-1800 ohm-meter. There are pockets of resistivity highs ranging from 2000 to 3400 ohm-meter along the banks of Idonyi River. This could be interpreted as sand units of the Ameki Formation (Okputong sandstone to the west) and Imo Formation (Umuna sandstone to the east) thickly accumulated along the banks of the river up to approximately $8 \mathrm{~m}$ depth probed at $\mathrm{AB} / 2=12 \mathrm{~m}$.

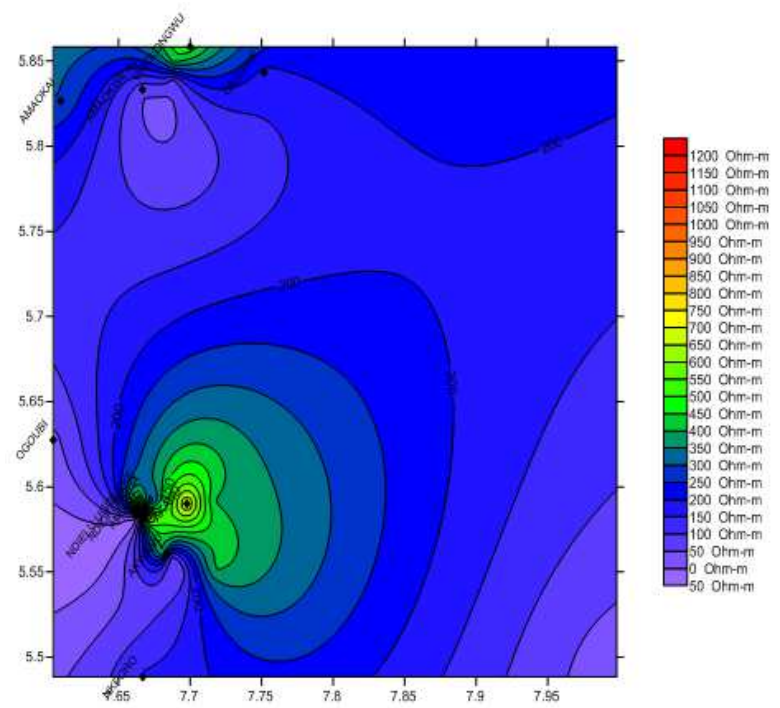

Figure 9. Iso-resistivity Image Map at $A B / 2=33 \mathrm{~m}$ (approximately $22 \mathrm{~m}$ depth probed)

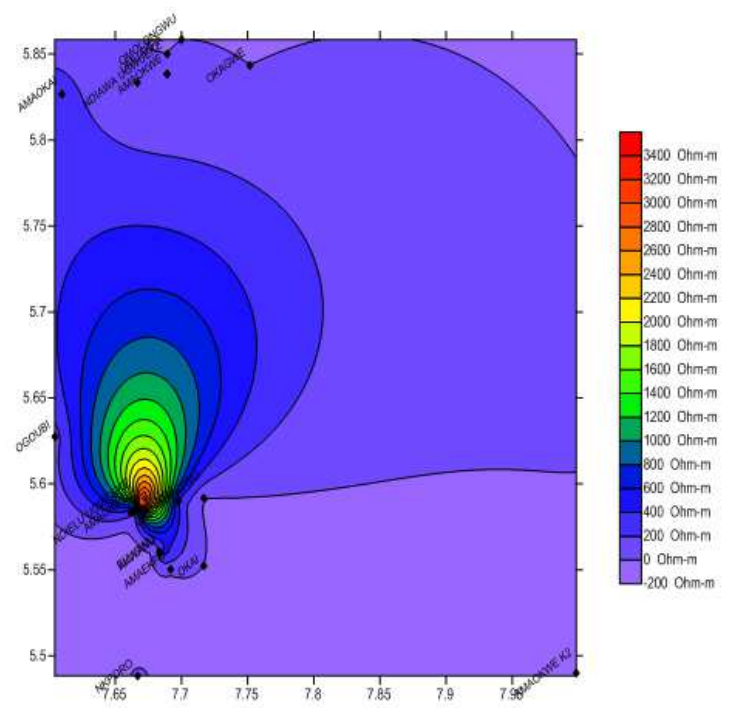

Figure 10. Iso-resistivity Image Map at AB/2 $=55 \mathrm{~m}$ (approximately $37 \mathrm{~m}$ depth probed)

The Isoresistivity map for $\mathrm{AB} / 2=33 \mathrm{~m}$ shown in Figure 9 above shows low resistivity values ranging from 50-350 ohm-meters bordering both the eastern, northeastern, western and southern parts of the study area. This shows that at this effective depth of $22 \mathrm{~m}$ probed, the Imo Formation dominates throughout the study area with pockets of resistivity highs between 450-1200 ohm-meters interpreted as the deposits of the Umuna Sandstone units of the Imo shale Formation. The Isoresistivity map for $\mathrm{AB} / 2=$ $55 \mathrm{~m}$ shown in Figure 10 above displays a high resistivity closure towards the western part of the study area. The overall resistivity at this depth of approximately $37 \mathrm{~m}$ ranges from 200-900 ohm-m with the peak well above 1000 ohm-meter. Figure 11 modeled the upper part of the fifth layer just below $37 \mathrm{~m}$. It shows at a glance that the Umuna sandstone unit dominates the eastern part indicating 
the presence of high sandy substratum with increasing depth within the area. From the 3-D image maps of the area produced (Figure 12), the western part of the study area is made up predominantly of shaly units while the eastern part of the study area is made up of sandy units. The river is stratigraphically controlled, the Umuna sandstone is exposed but not found everywhere in the study area but grades laterally with increasing depth well encountered below $37 \mathrm{~m}$. These resistivity values observed in the $3 \mathrm{D}$ image of the computer modeled VES data are in agreement with the theoretical values of the sand/shale group resistivity discussed.

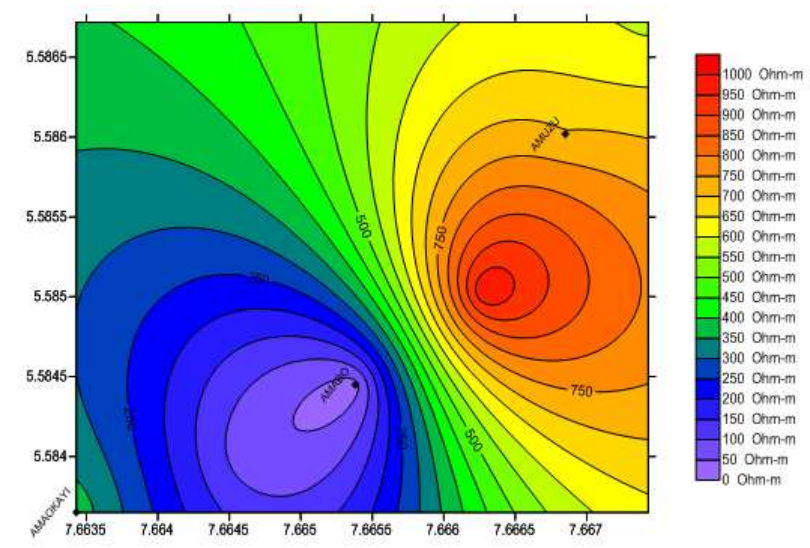

Figure 11. Iso-resistivity Image map of Layer 5 (>37m depth probe)

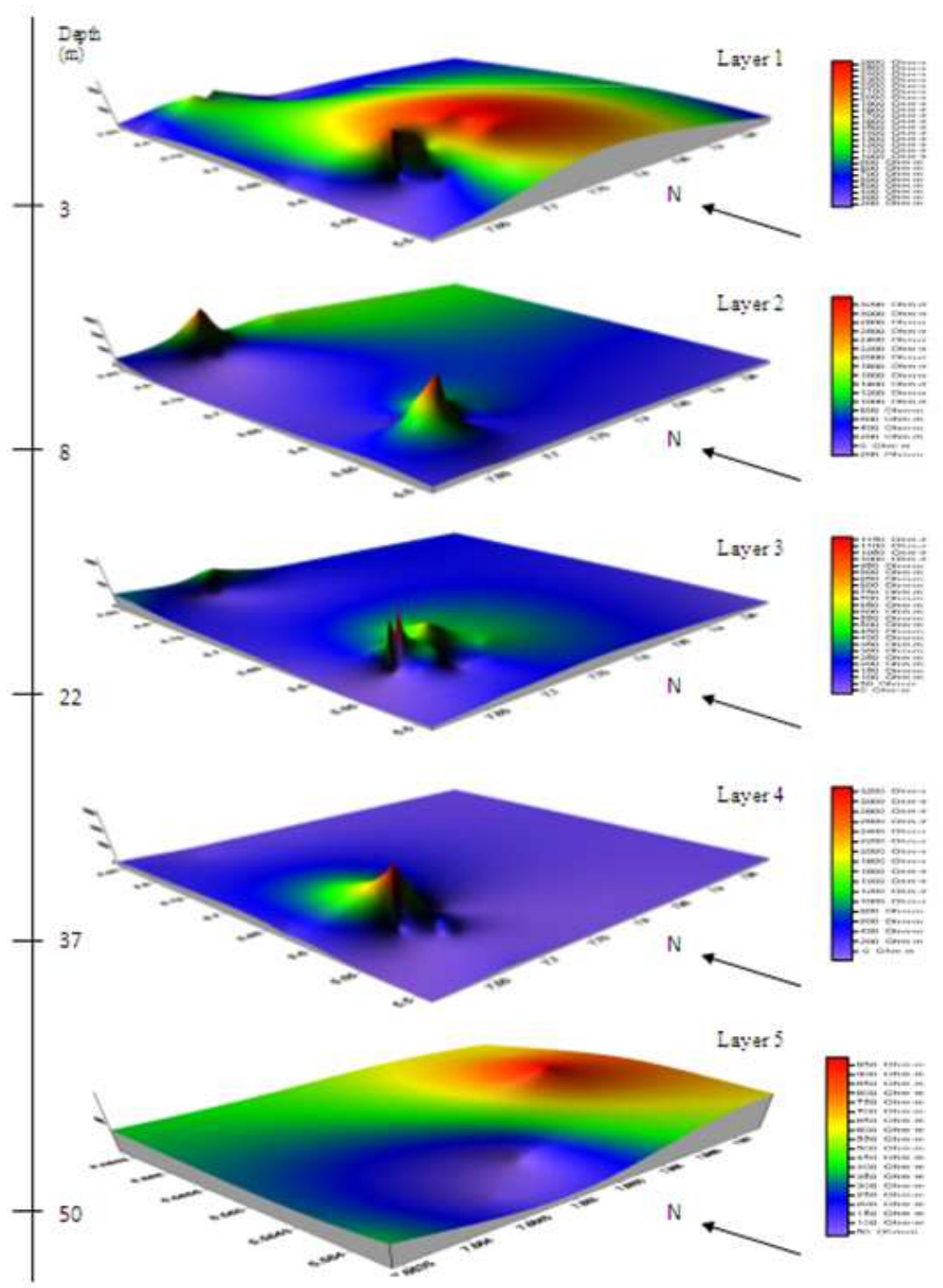

Figure 12. 3-D Display of Resistivity variations within each Interpreted Layer

\section{Conclusion and Recommendation}

Based on our knowledge of the geological formations in the study area from the geology of Nigeria supported by the observation made in the field, it is proven that the area is made up of mainly Tertiary Imo Formation outcrop eastward while Eocene Ameki Formation outcrops to the west. The Tertiary Imo Formation consists of medium to coarse grained poorly consolidated sands with lateritic soil while the Eocene Ameki Formation has sandy shale at very 
low shallow depths with underlying shale beyond $30 \mathrm{~m}$ depth. From the foregoing investigations, considering the geological problems associated with the study area, there is no indication of faults down to the depth of approximately $40 \mathrm{~m}$ modeled. Furthermore, the present study has helped to map out shaly and sandy zones, identifying the actual cause of the failed local dam constructed in 1960s in the area. All these noted properties of the formations in the investigated area (Amaeke-Abam, Southeastern Nigeria) suggest that the area will offer an excellent site for dam construction. Sandstone-Shale-Limestone areas have been known to be good dam sites as recorded by [18]. Sandstones support dam construction when they act as abutment ends, because they are non-plastic, not susceptible to plastic deformation, not subject to rapid surface deterioration on exposure, not easily compacted and not cohesive; though potentially prone to infiltration and must be considered. Shales can be used for making embankment and reservoir blanket in dam construction because of their impermeable nature. This makes them to be very useful in dam construction. Layers interbeded with shale may constitute potential sliding surfaces. The shale in the western part of the study area would also be good for abutment end because it is embedded with traces of sandstone as revealed by the VES results. The failure of a previous dam near the river is thus attributable to much seepage due to overriding sandy substratum. Thus the area, although can support the weight of any dam, may have seepage problems. The area, being the most fertile area (phosphatic Ameki units) with CRIN, RRIN, FRIN, NCRIN having research institutions near the river, a dam is necessary here and this study has shown that it is possible to have a dam with solid foundation. However, we suggest a baseline data survey of water quality before any construction so as to monitor any contamination trend due to impoundment.

\section{References}

[1] Jansen,R.B (1988). Advance dam engineering for design, construction and rehabilitation. Technology and engineering, U.S.A. p 811 .

[2] Chukweze, H.O. (1990). Advance Engineering Soil Mechanics; Humoch Nigeria Association; Pp.1-50.

[3] Robert, F.L. and Hatheway, A.W. (1988). geology and engineering; Mc-graw Hill Book Coy; pp 1-100, 587.

[4] John, A.F. and Dusseault M.B., (1989). rock engineering; McGraw-Hill, New York.
[5] Ajayi O. Olorunfemi M.O, Ojo J.S, Adegoke - Anthony C.W, Chikwendu K.K, Oladapo M.I, Idornigie AL, Akinluyi F. (2005). Intergrated geophysical and geotechnical investigation of a dam site on Rver Majyo Ini, Adamawa State, Northern Nigeria. Afri. Geosc. Rev. 12(3), 179 - 188.

[6] Bayewu O. O., Oloruntola M. O., Mosuro G. O. and Abass O. K. (2012). Preliminary Investigation of a Proposed Dam Site along River Ome, Ago Iwoye South Western Nige- ria," Journal of Science and Technology, 1(6), 308-315.

[7] Olasunkanmi N. K., Olatunji S., Akoshile C. O. and Nwankwo L. I. (2012) Geoelectrical Assessment of University of Ilorin Dam Axis," Archives of Physics Research, 3( 3), 221-231.

[8] Kilty, K. T., Norris, R. A., Mc Lamore, W. R., Hennon, K. P. and Euge, K. (1986). Seismic Refraction at Horse Mesa dam: An application of the generalized reciprocal method. Geophysics, 51(2), $266-275$.

[9] Annor, E. A., Olasehinde, P. L. and Pal, P. C. (1989), A geological evaluation of a Prospective site for a Weir in the River Oyin, Ilorin, Nigeria. Zangew: Geowiss, heft 8, S. 83 -90 .

[10] Ojo, J. S. and Olorunfemi, M. O. (1995). Geoelectric Mapping of a Near Vertical Contact: A case study Around Erusu, Ikare Area, South-Western Nigeria. Journal of Mining and Geology. 13(2), $151-153$.

[11] Olasehinde, P. I. and Adelana, S. M. A. (1999). A Geophysical Investigation of a Proposed Dam Site in Southwestern Nigeria. Water Resources.10, 50 - 54.

[12] Ibeneme S. I., Ibe K.K., Selemo A.O., Udensi S.C., Nwagbara J.O., Eze I.O., Ubechu B.O., Onwuka C.O. (2013). Geoelectrical Assessment of a Proposed Dam Site around Ehuhe area of Oji River, Southeastern Nigeria. Journal of Natural Sciences Research 3(13), 163-170.

[13] Lowrie, W. (1997). Fundamental of Geophysics. Cambridge University press.UK, 165-228.

[14] Telford, W. M., Geldert L.P., Sheriff R. B. and Keys D. A. (1982). Applied Geophysics. Cambridge University press, second edition, 635-642.

[15] Azm, S.A; Sofwan K.S. and Hussein A.I.; (1994). Engineering Geology Vol. 38; Elsevier Amsterdam.

[16] Dobrin, M.B. (1960). Introduction To Geophysical Prospecting; Mc-Graw Hill Book Co, 569, 571, 591

[17] Zohdy, A.A.R. (1975). Automatic Interpretation of Schlumberger Sounding Curves using Dar Zarouk Function. US. Geol. Surv. Bull. 39, 1313-E.

[18] Ibe K.K. (1999). Geoelectrical sounding of the Northern section of Bauchi road campus, University of Jos Nigeria. Journal of environmental sciences. 3(2), 140-146. 